\title{
IDENTIFIKASI POLA PENGENALAN LITERASI PADA ANAK USIA DINI DI KOTA MATARAM
}

\author{
Nani Husnaini \\ Prorgram Studi Pendidikan Islam Anak Usia Dini FTK UIN Mataram \\ e-mail: nanihusnini@uinmataram.ac.id
}

\begin{abstract}
Abstrak
Penelitian ini bertujuan untuk mengetahui pola pengenalan literasi pada anak usia dini di Kota Mataram yang mencakup konsep pengenalan literasi pada anak usia dini di kota mataram, prosedur pengenalan literasi pada anak usai dini di kota mataram, media apa saja yang digunakan dalam pengenalan literasi pada anak usia dini di kota mataram, metode apa saja yang digunakan pengenalan literasi pada anak usia dini di kota mataram, dan capaian kemampuan literasi anak usia dini di kota mataram. Metode penelitian menggunakan pendekatan kualitatif, dengan metode pengumpulan data melalui observasi, wawancara dan dokumentasi. Adapun hasil penelitian menemukan bahwa 1) Konsep pengenalan literasi pada anak usia dini di beberapa TK/PAUD yang menjadi sasaran penelitian menunjukkan bahwa, pengenalan literasi dimaknai sebagai suatu proses pengenalan baca-tulis dasar pada anak untuk mempersiapkan anak melanjutkan studi pada jenjang berikutnya dengan tahapan, perbedaan kemampuan anak, materi serta metode pembelajaran yang diterapkan, 2) Pengenalan literasi pada anak usia dini di Kita Mataram dilakukan secara bertahap dengan memperhatikan tahap perkembangan anak. pengenalan literasi dimulai dari mengenalkan bentuk huruf, membaca dan menulis kata hingga membaca dan menulis kalimat sederhana. 3) Media yang digunakan dalam pengenalan literasi pada anak usia dini sangat bervariasi, seperti kantong huruf, kartu huruf, puzzle huruf, buku cerita, pohon literasi, balok huruf, dimana dalam penggunaan media juga tergambar tahapan pengenalan literasi yang disesuaikan dengan usia dan kemampuan anak usia dini. 4) Metode pengenalan literasi dengan metode bercerita, bermain, dan menyanyi. 5) Kemampuan anak dalam membaca dan menulis permulaan dapat dilihat ketika sudah memasuki semester dua, khususnya kelas B. Rata-rata anak sudah mampu membaca kalimat sederhana.
\end{abstract}

Kata Kunci: pola, literasi, anak usia dini

\section{PENDAHULUAN}

Literasi merupakan salah satu tugas perkembangan anak yang harus distimulasi sejak dini. Literasi secara sederhana dimaknai sebagai kemampuan baca-tulis. Namun ada kesalahan dalam memahami posisi literasi dan hubungannya dengan kemampauan anak usai dini. Kebanyakan orangtua menuntut agar anaknya dapat membaca dan menulis sedini mungkin. Fokusnya bukan pada pengenalan literasi, namun pada target kemampuan anak menguasai literasi sejak dini. Tuntutan orang tua tersebut membuka celah "memaksa" anak untuk belajar membaca dan menulis. Sehingga sekolah berusaha memompa kemampuan anak untuk menunjukkan kemampuan sekolah dalam mengembangkan dan melejitkan kemampuan baca-tulis anak. Upaya yang cukup kuat ini cenderung mengabaikan kemampuan dan karakteristuk anak usai dini yang lebih menekankan pengembangan minat di banding kemampuan. Sehingga tidaklah berlebihan jika pemerintah mengantisipasi hal tersebut dengan mengeluarkan kebijakan larang pembelajaran baca tulis di TK, sebagaimana rilis Republika.co.id tentang pernyataan Direktur Pembinaan sekolah dasar Kemendikbud Wowon widaryat, menyatakan bahwa pihaknya 
mengeluarkan aturan bahwa Sekolah Dasar tidak boleh mensyaratkan kemampuan calistung sebagai syarat masuk SD. Kebijakan yang dikeluarkan oleh Kemendikbud sangatlah beralasan, karena banyak Sekolah Dasar yang tidak menerima siswa yang bisa membaca, menulis dan berhitung. Persyaratan yang dibuat oleh beberapa SD, mendoktrin pemahaman orang tua jika anaknya yang masih TK sudah wajib belajar membaca bahkan harus bisa calistung. Pemahaman inilah yang memunculkan tuntutan dari orang tua agar sekolah (PAUD) mampu mengajari anak-anak baca-tulis dengan target lulus TK sudah bisa membaca. Maka tidak sedikit lembaga PAUD yang menjadikan target calistung sebagai "nilai jual” sekolahnya. Larangan pembelajaran baca-tulis pada lembaga PAUD ditaati hanya sebatas sebagai upaya menghindari sanksi dari pemerintah, bukan pada tujuan substantive untuk menghindari proses pembelajaran tekstual yang jauh dari prinsip-prinsip pembelajarn anak usia dini. Berdasarkan wawancara dengan salah satu Kepala Sekolah RA di Kota Mataram: "pembelajaran membaca dan menulis tidak dapat dihindari, karena kemampuan baca-tulis menjadi prasyarat masuk SD, namun disisi lain, pemerintah melarang baca-tulis. Sehingga kami mensiasatinya dengan memberikan les pada anak-anak di luar jam sekolah”.

Sebenarnya, permasalahannya bukan pada boleh tidaknya membaca dan menulis, akan tetapi penggunaan motede, media dan pola pengenalan yang tepat, sesuai dengan perkembangan anak usia dini (AUD). Bahkan seorang pakar neurologis, Glenn Doman berdasarkan hasil penelitiannya, merekomendasikan agar kegiatan belajar membaca dilaksanakan sejak bayi. Menurut William Greenough dari Univercity of Illionis, kelebihan sinaps yang disusul oleh hilangnya kelebihan itulah yang menimbulkan pola dalam otak. Pada usia 18 tahun, potensi yang bakat dan kecendrungan latennya dibentuk berdasarkan pengalaman sejak bayi sudah terpola dan siap untuk berkembang. Setelah itu otak tidak akan pernah mampu untuk menguasai kemahiran baru atau bangkit kembali dari kekeliruan semudah yang terjadi pada masa kanak-kanak. Jadi, pengenalan literasi pada AUD, bukan tidak boleh, justru sangat dianjurkan, yang tidak boleh adalah ketika menggunakan metode, media dan pola yang tidak tepat karena mengejar target bisa baca-tulis. Oleh sebab itu, peneliti ingin memotret lebih dekat, mengamati lebih cermat dan menelaah lebih mendalam tentang pola pembelajaran calistung di lembaga PAUD di Kota Mataram. Namun agar penelitian ini lebih fokus dan dapat menghasilkan data-data yang lebih berkualitas dan valid, penelitian ini dibatasi pada aspek membaca dan menulis saja atau yang dikenal dengan istilah literasi (keaksaraan atau baca tulis). Maka dari itu penelitian ini berjudul "Identifikasi Pola Pengenalan Literasi pada Anak Usia Dini di Kota Mataram”

\section{METODE}

\section{Jenis Penelitian}

Penelitian ini menggunakan menggunakan pendekatan kualitatif dengan jenis penelitian deskriptif. Penelitian deskriptif bertujuan untuk meneliti dan menemukan informasi sebanyak-banyaknya dari suatu fenomena. Dalam penelitian ini, peneliti akan mencoba mengungkapkan data-data yang berkaitan dengan pola pengenalan literasi anak uasi dini, kemudian data dan fenomena tersebut dianalisis sehingga dapat ditarik suatu kesimpulan. Menurut Sugiono, metode Penelitian adalah suaru cara ilmuai untuk mendapatkan data penelitian dengan tujuan dan kegunaan tertentu.

Dalam penelitian ini juga peneliti menggunakan penelitian ini lapangan (field research), yaitu peneliti terjun langsung ke dalam lingkungan subjek penelitian agar mendapatkan data-data yang dibutuhkan terkait dengan pola 
pengenalan literasi pada anak usia dini di Kota Mataram.

\section{Lokasi dan Waktu Penelitian}

Tempat Penelitian

Penelitian ini dilaksanakan di Kota Mataram dengan mengambil focus pola pengenalan literasi yang mencakup pada konsep, prosedur, metode, media dan evaluasi pengenalan literasi pada anak usia dini yang diterapkan pada lembaga PAUD di Kota Mataram yang terdiri dari PAUD Semau Harapan Bangsa, TK Negeri Pembina Mataram dan PAUD AlHikmah. Adapun waktu penelitian akan dilaksanakan sesuai dengan jadwal yang akan ditetapkan oleh LPPM UIN Mataram. Namun, agar penelitian ini lebih terarah, maka peneliti merencanakan pelaksanaan penelitian sejak bulan april hingga Nopember 2018.

\section{Data dan Sumber Data}

Sumber data dalam penelitian ini adalah pihak-pihak yang dapat memberikan informasi mendalam tentang pola pengenalan literasi untuk anak usia dini, meliputi kepala sekolah dan guru pada TK dan PAUD yang menjadi subyek penelitian.

\section{Metode dan Penentuan Subyek Penelitian}

Penelitian ini dilkukan di Kota Mataram dengan mengambil tiga sekolah sebagai subyek penelitian, yaitu TK Negeri Pembina Mataram, PAUD AlHikmah dan PAUD Semai Harapan Bangsa. Pemilihan subyek penelitian dengn memprtimbangkan keragaman karakteristik sekolah baik dari sisi kelengkapan sarana prassarana, latar belakang siswa dan kualitas guru. Hal tersebut dimaksud untuk memperoleh gambaran yang komprehensif dan efresentatif tentang pola pengenalan literasi pada anak usia dini di Kota Mataram.

\section{Metode Pengumpulan Data}

Menurut Sugiyono, dalam penelitian kualitatif, pengumpulan data dilakukan pada natural setting (kondisi alamiah), dan teknik pengumpulan data lebih banyak pada observasi berperan serta (participant observation), wawancara mendalam (Indepth interview) dan dokumentasi. ${ }^{1}$ Oleh karena itu maka teknik pengumpulan data yang diginakan dalam penelitian ini adalah sebagai berikut:

a. Pengamatan (Observasi)

Menurut Ridwan (2010:104) yang dimaksud dengan observasi adalah pengamatan secara langsung ke objek penelitian untuk melihat dari dekat kegiatan yag dilakukan. Metode observasi digunakan dalam penelitian ini yaitu mengamati dan mencatat secara sistematis proses pengenalan literasi untuk anak usia dini di tiaptiap sekolah yang sudah ditentukan.

b. Metode Dokumentasi

Pada penelitian ini juga menggunakan metode dokumentasi, agar hasil penelitian yang dilakukan semakin kredibel, data yang akan dikumpulkan dapat berupa dokumen $\mathrm{RKH}$, foto-foto kegiatan, hasil penilain pembelajaran anak dan lainnya yang terkait pola pengenalan literasi anak usia dini.

c. Metode Wawancara

Adapun pengumpulan data pada penelitian ini menggunakan wawancara terstruktur, dimana pedoman wawancara dijabarkan dalam bentuk deskripsi. Wawancara dilakukan melalui tanya jawab kepada narasumber untuk memperoleh informasi mengenai pola pengenalan literasi pada anak uasia dini. Wawancara yang telah disiapkan oleh peneliti ditujukan kepada kepala sekolah, guru dan siswa untuk memperoleh data yang diperlukan.

\section{Metode Analisis Data}

Teknik analisis data yang digunakan pada penelitian ini adalah analisis data model Miles and Huberman. Miles and 
Huberman (dalam Sugiyono, 2011: 246), mengemukakan bahwa aktivitas dalam analisis data kualitatif dilakukan secara interaktif dan berlangsung secara terus menerus sampai tuntas, sehingga datanya sudah jenuh. Aktivitas dalam analisis data yaitu data reduction, data display dan conclusion drawing/verification.

\section{a. Reduksi Data}

Mereduksi data berarti memilih data/merangkum data, memilih halhal pokok, memfokuskan pada halhal penting, mencari tema dan polanya serta membuang hal-hal yang tidak perlu. Dengan demikian, data yang telah direduksi akan memberikan gambaran yang jelas dan mempermudah peneliti untuk melakukan Pengumpulan data. Data yang dianggap penting adalah data yang berkaitan dengan pola pengenalan literasi pada anak usia dini.

b. Penyajian data

Setelah mereduksi data, tahap selanjutnya adalah menyajikan data, agar data yang banyak dan telah melalui tahap reduksi dapat difahami dengan mudah oleh peneliti maupun orang lain. Bentuk penyajian data dalam penelitian ini adalah narasi teks. Dengan kata lain, data yang telah diperoleh melalui observasi, wawancara dan dokumentasi dianalisis dengan teori-teori yang relevan agar dapat mendeskripsikan dengan jelas tentang pola pengenalan literasi pada anak usia dini di Kota Mataram.

c. Kesimpulan

Data yang sudah diperoleh kemudian difokuskan, disusun secara sistematis dalam bentuk narasi. Kemudian data tersebut disimpulkan sehingga makna data dapat ditemukan dalam bentuk tafsiran dan argumentasi.

\section{HASIL DAN PEMBAHASAN Konsep Pengenalan Literasi pada Anak Usia Dini di Kota Mataram}

Berdasarkan paparan data hasil penelitian, konsep pengenalan literasi pada anak usia dini di beberapa TK/PAUD yang menjadi sasaran penelitian menunjukkan bahwa, pengenalan literasi pada PAUD di Kota Mataram merupakan suatu proses pengenalan baca-tulis dasar pada anak yang dalam pelaksanaannya tetap memperhatikan perbedaan kemampuan anak, tahapan usia yang disesuaikan dengan materi yang diberikan, menerapkan metode bermain dan menggunakan media yang bervariatif dan menarik. Tujuan pengenalan literasi pada anak usia dini di Kota Mataram adalah untuk menudukung kesiapan anak melanjutkan pendidikan ke tahap berikutnya.

Hal ini selajalan dengan tujuan pendidikan anak usia dini yang tercantum dalam undang-undang nomor 20 Tahun 2003 tentang Sistem Pendidikan Nasional, Bab 1, Pasal 1, butir 14 dinyatakan "pendidikan anak usia dini adalah suatu upaya pembinaan yang ditujukan kepada anak sejak lahir sampai dengan usia enam tahun yang dilakukan melalui pemberian rangsangan pendidikan untuk membantu pertumbuhan dan perkembangan jasmani dan rohani agar anak memiliki kesiapan dalam memasuki pendidikan lebih lanjut”.

Pengenalan literasi pada anak usia dini dengan pendekatan holistic-integratif. Pengenalan literasi terintegrasi dalam proses pembelajaran. Pada sekolah dengan pengelolaan kelas bersifat sentra, pengenalan litreasi dominan dilaksanakan pada sentra persiapan namun tetap sejalan dengan pengembangan enam aspek perkembangan anak usia dini. Yaitu, aspek kognitif, bahasa, social emosional, seni, nilai moral dan agama, dan fisik motoric. Begitu juga pada sentra lainnya, yaitu pada sentra alam, sentra balok, sentra agama, dan sentra seni. Kegiatan pembelajaran pada tiap sentra tersebut dilaksanakan dengan tujuan pengembangan keenam aspek yang termasuk di dalamnya pengenalan literasi. 
Selain terintegrasi dalam proses pembelajaran. Pengenalan literasi juga dapat dikatakan bersifat holistic, karena pengkondisian lingkungan kelas maupun lingkungan sekolah yang kaya akan nuansa literasi. Misalkan pada bendabenda atau mainan, juga dilabeli dengan tulisan. Di setiap sudut ruang di isi dengan tulisan. Kondisi ini merupakan dapat menjadi upaya mengakrabkan dan menumbuhkan minat anak pada dunia literasi. Hal ini relevan dengan teori Combourne yang menjelaskan 7 kondisi yang kondusif dalam pengembangan kemampuan baca-tulis anak, salah satunya yaitu: Penenggelaman (immersion), yamg dimaknai sebagai upaya untuk menciptakan lingkungan fisik anak-anak agar berada dalam lingkungan budaya keaksaraan.

Dari empat TK yang dijadikan sampel, hanya TK Negeri Pembina yang mengadkan jam tambahan untuk penguatan kemampuan literasi anak, yang mulai dijadwalkan saat anak semester dua dan melibatkan selruh anak. Artinya, selain pendekatan terintegrasi, TK Negeri Pembina juga mengajarkan literasi atau baca-tulis secara parsial. namun kegiatan tambahan tersebut tetap memperhatikan metode yang sesuai dengan perkembangan anak.

\section{Prosedur Pengenalan Literasi pada} Anak Usia Dini di Kota Mataram

Pengenalan literasi pada anak usia dini di Kita Mataram dilakukan secara bertahap dengan memperhatikan tahap perkembangan anak. Pada pengenalan membaca misalnya, pada usia kelompok bermain, masih sebatas pengenalan namanama huruf dengan penekanan bagaimana anak mengingat bentuk huruf. Sebagaimana keterangan salah satu guru TK Pembina Mataram, dalam mengenalkan huruf "O", guru mengasosiasikan huruf tersebut dengan bentuk donat. Hal ini bertujuan untuk menstimulasi kekuatan ingatan anak.

Begitupula pada kemampuan menulis. Latihan dasar dimulai dengan membuat garis lurus, melengkung dan pola-pola lainnya, kemudian menulis huruf dengan menyambung garis putus-putus, selanjutnya meniru tulisan hingga menulis mandiri. Morrow (dalam Nurdhiana, 2008:3.11) membagi tahapan menulis anak menjadi 6 tahapan (1) Writing via drawing (menulis dengan cara menggambar). (2) Writing via scribbling (menulis dengan cara menggores). (3) Writing via making letter-like forms (menulis dengan cara membentuk seperti huruf). (4) Writing via reproducting well learned unit or letter stings (menulis dengan cara menghasilkan huruf atau unit yang sudah baik), seperti mencoba menuliskan namanya. (5) Writing via invented spelling (menulis dengan mencoba mengeja satu persatu). (6) Writing via conventional speeling (menulis dengan cara mengeja langsung).

Media Pengenalan Literasi pada Anak Usia Dini di Kota Mataram

Media yang digunakan dalam pengenalan literasi pada anak usia dini cukup beragam seperti kantong huruf, kartu huruf, puzzle huruf, buku cerita, pohon literasi, dan lainnya. Dari penggunaan media, diperoleh gambaran tentang tahapan pengenalan literasi pada anak usia dini. Contohnya, pada penggunaan media kartu huruf, mulai dari tahapan anak mengenal huruf, kemudian merangkai kata bahkan hingga menyusun kalimat, tergambar pola pengenalan literasi secara bertahap. Begitu juga dalam penggunaan buku cerita. Pada mulanya anak hanya membaca gambarnya saja, kemudia seiring dengan pengetahuan anak tentang huruf, anak mulai mengasosiasikan beberapa huruf dengan kata atau kalimat yang merepresetasikan gambar hingga pada tahap anak dapat membaca kalimat cerita dan memahami artinya. Hal ini sejalan dengan teori tahapan membaca pada anak usai dini yang di kemukakan oleh Menurut Jamaris, ia membagi tahap perkembangan membaca anak dapat dalam empat tahap; (1) Tahap timbulnya 
kesadaran terhadap tulisan yang ditandai dengan kegemaran anak melihat-lihat dan membolak balik buku dan anak mulai menyadari bahwa buku itu penting. (2) Tahap membaca gambar, pada tahap ini anak berpura-pura membaca buku dengan mencocokkan gambarnya walaupun tidak sesuai dengan tulisan. Anak menyadari bahwa buku memiliki karakteristik tertentu, seperti judul, halaman, kata dan kalimat serta tanda baca. (3) Tahap pengenalan bacaan, dimana anak dapat menggunakan tiga sistem bahasa, seperti fonem (bunyi huruf), semantik (arti kata) dan sintaksis (aturan kata dan kalimat). (4) Tahap membaca lancar, pada tahap ini anak sudah dapat membaca lancar berbagai jenis buku berbeda dan bahanbahan yang langsung berhubungan dengan kehidupan mereka sehari-hari.

\section{Metode Pengenalan Literasi pada Anak Usia Dini di Kota Mataram}

Seperti halnya media, metode pengenalan literasi pada anak usia dini di Kota Mataram sesuai dengan kaidah prinsip-prinsip pembelajaran pada anak usia dini. Bercerita, bermain dan bernyanyi merupakan metode yang diterapkan dalam pengenalan literasi.

Menurut Takdirotun Musfiroh, metode bercerita sangat efektif dalam menstimulasi minat baca-tulis anak. Membacakan cerita dapat menjadi contoh yang efektif bagi anak bagaimana aktivitas membaca harus dilakukan. Secara tidak langsung, anak memperoleh contoh tentang orang yang gemar dan pintar membaca dari apa yang dilihatnya. Anak yang sering memperoleh contoh, dengan dibacakan cerita, minat bacanya akan tumbuh secara sukarela. Anak pun akan belajar mengidentifikasi lambinglambang tulis dalam rangkaian kata dan dalam rangkaian kalimat.

Musfiroh juga mengemukakan pendapat Leonhardt tentang kecerdasan bahasa anak. Menurutnya, cerita memancing kebahasaan anak. anak yang gemar mendengar dan membaca cerita, akan memiliki kemampuan berbicara, menulis dan memahami gagasan rumit secara lebih baik. Menurut Musfiroh, pernyataan Leonhardt cerita juga membantu menumbuhkan kemampuan menulis anak. cerita dapat menimbulkan inspirasi anak untuk membuat cerita. Dengan kata lain, cerita dapat menstimulasi anak untuk membuat cerita sendiri.

\section{Capaian Kemampuan Literasi pada Anak Usia Dini di Kota Mataram}

Berdasarkan hasil penelitian yang diperoleh dari wawancara dengan informan, kemampuan anak dalam membaca dan menulis permulaan dapat dilihat ketika sudah memasuki semester dua, khususnya kelas B. Rata-rata anak sudah mampu membaca kalimat sederhana. Hanya sebagian kecil yangmasih kesulitan. Capaian anak juga sangat dipengaruhi oleh faktor keluarga, bagaimana peran orangtua di rumah dalam mendukung kemampuan literasi anak, misalkan dengan mengajak membaca bersama atau bertanya tentang apa yang sudah dipelajari anak di sekolah dan mengajak anak mengulangi pelajaran di rumah.

Selain perhatian dan dukungan orang tua, beberapa hal yang juga mempengaruhi perkembangan bahasa anak, termasuk di dalamnya kemampuan literasi yaitu, a) Intelegensi (Proses Memperoleh Pengetahuan), Tinggi rendahnya kemampuan berfikir seseorang sangat berpengaruh pada kualitas literasinya. Bagaimanapun proses literasi melibatkan proses kognitif seseorang. Pada seorang anak, kempuan mengenali abjad dan merangkainya dalam bentuk suku kata dan kata sederhana sangat terkait dengan kematangan kemampuan berfikirnya, kerana membaca dan menulis melibatkan pemahaman dan hafalan, b) Status Sosial, Anak yang secara sosial budaya berasal dari kalangan atas dan menengah kemampuan literasinya lebih baik daripada anak yang berasal dari kalangan bawah. Anak dari kalangan menengah ke atas dapat mencapai 
peringkat tertinggi dalam prestasi literasi. Hal ini disebabkan oleh kesempatan dan kondisi yang ia peroleh. Anak dalam keluarga yang mapan secara ekonomi dan social lebih memiliki kesempatan baik berupa fasilitas baca-tulis maupun pengalaman luterasi lainnya, c) Jumlah Anak atau Jumlah Keluarga, Jumlah keluarga sangat mempengaruhi tingkat kemampuan literasi seorang anak. Suatu keluarga yang memiliki banyak anggota keluarga, kemampuan literasi anak lebih meningkat, karena terjadi komunikasi yang bervariasi dibandingkan dengan yang hanya memiliki anak tunggal dan tidak ada anggota lain selain keluarga inti, d) Jenis Kelamin, kemampuan

literasi anak perempuan lebih baik daripada anak laki-laki. Anak perempuan lebih dahulu mampu berbicara daripada anak laki-laki, sehingga perbendaharaan kosakata anak perempuan lebih banyak daripada anak laki-laki. Namun perbedaan jenis kelamin ini akan berkurang secara tajam selaras dengan bergulirnya fase perkembangan dan bertambahnya usia.

Menurut Mukhlis (2017) terdapat enam teknik yang dapat digunakan untuk menstimulasi literasi anak usia dini, yaitu:

- Membaca dengan keras dan banyak berbicara. Orangtua dan atau pendidik sering mengalami kesulitan dalam menemukan cara yang efektif untuk menumbuhkan literasi dengan mengenalkan buku dan menyampaikan informasi untuk anak. Membaca buku dengan keras merupakan hal sederhana yang dapat menarik minat anak untuk mencari tahu hal-hal yang ada di dalam buku. Pilihlah buku yang sesuai dengan minat anak agar terjadi proses yang dinamakan dialogue recording. Dialogue recording adalah percakapan alami tentang buku yang dibaca, membuat anak merasa ikut mengalami peristiwa tersebut, menarik perhatian dan meningkatkan pengalaman anak, membaca dengan keras dapat membantu anak-anak dalam membangun kosakata, konsep dan intelektual.

- Menempelkan logo huruf di sekitar kelas atau rumah. Menempelkan pelbagai media di sekitar lingkungan adalah cara yang tepat untuk mengenalkan secara langsung dan bisa dilakukan kapan saja. Ketika anak melihat label huruf, angka dan tanda bada di sekitarnya itu merupakan sebuah pengalaman yang menarik bagi setiap anak. Anak secara langsung terbiasa dengan perlbagai simbol aksara dan mulai mengenali pelbagai simbol. Tugas orang tua dan atau pendidik adalah memberikan stimulasi yang menarik dengan menghubungkan simbolsimbol tersebut ke dalam kehidupan sehari-hari anak. misalnya menggunakan tongkat untuk mengenali angka satu, kursi untuk angka empat. Selain itu juga dapat menggunakan kartu atau stiker yang bergambar huruf dengan pelbagai modifikasi. Anak usia 2-4 tahun yang sering melihat label atau simbol yang ada di sekitarnya akan membuat anak cepat dalam mengenali kata-kata yang terlihat yang merupakan pondasi awal untuk membaca. Strategi ini memungkinkan anak usia dini untuk mempelajari konsep tentang sebuah kata, membaca petunjuk dengan melihat logo yang ditempel, bahkan menguasai dasardasar untuk mengeluarkan sebuah kata melalui penggunaan tindakan secara langsung. Pola pengenalan literasi dengan teknik ini efektif untuk membantu anak usia dini mengenal pola huruf (decode) dan menarik minat anak untuk bukan hanya sekedar mengeja, namun juga mengucapkan nama-nama benda di sekitar mereka.

- Merancang literasi multisensor. Strategi literasi multisensor meliputi bernyanyi, berbaris, seni, dan kerajinan tangan, gerakan fisik serta 
kegiatan mencicipi. Orang tua atau pendidik dapat menggunakan salah satu maupun campuran dari beberapa kegiatan tersebut untuk membantu anak menikmati sekaligus tertarik untuk mempelajari literasi. Aktivitas literasi untuk anak usia dini harus melibatkan keceriaan dalam setiap pengenalan literasi. Ajarkan anak untuk mengucapkan bunyi huruf terlebih dahulu sebelum memberitahukan hurufnya. Anak usia dini masih dalam masa yang senang bermain, sehingga butuh strategi melibatkan aktivitasnya secara langsung untuk mengenali literasi. Aktivitas seperti makan, minum, mandi, dan lain sebagainya sebisa mungkin menggunakan perangkat yang melibatkan langsung penggunaan literasi. Seperti di kotak mainan, di buku dan lain sebagainya.

- Bergembira dengan suara. Kegiatan ini bisa dimulai dengan suku kata berirama dan bertepuk tangan. Akhirnya akan mengarah pada belajar tentang fonem, suara yang membentuk kata-kata. Kegiatan ini dapat menyampaikan konsep abstrak, fonem menggunakan benda-benda konkret seperti kepala, pundak, lutut, kaki dan sebagainya.

- Mewarnai, menggambar, menulis dan membacanya kembali. Kegiatan yang melibatkan pensil dan kertas dapat membantu anak-anak untuk mengaktifkan minat literasi melalui aktivitas seni sederhana, seperti mencoret-coret, mewarnai, menggambar dan berpura-pura menulis pada awal masa kanakkanak. Kegiatan menggambar dan menulis dapat membantu anak untuk mengkoordinasikan dan menerapkan semua aspek awal membaca. Orang tua atau pendidik dapat menstimulasi anak untuk seolah-olah membaca hasil coretan, gambar, tulisan atau apapun karya anak. Kegiatan tersebut merupakan salah satu cara sederhana yang mampu membantu anak untuk lebih lancar dalam mengucapkan kata-kata dan dapat menarik rasa keingin tahuannya akan literasi.

\section{KESIMPULAN}

Berdasarkan pemaparan data pada hasil penelitian dan pembahasan, maka pola pengenalan literasi pada anak usia dini di Kota Mataram sebagai berikut:

Konsep Pengenalan Literasi pada Anak Usia Dini di Kota Mataram

Konsep pengenalan literasi pada anak usia dini di beberapa TK/PAUD yang menjadi sasaran penelitian menunjukkan bahwa, pengenalan literasi dimaknai sebagai suatu proses pengenalan bacatulis dasar pada anak untuk mempersiapkan anak melanjutkan studi pada jenjang berikutnya dengan tahapan, perbedaan kemampuan anak, materi serta metode pembelajaran yang diterapkan.

Prosedur Pengenalan Literasi pada Anak Usia Dini di Kota Mataram

Pengenalan literasi pada anak usia dini di Kita Mataram dilakukan secara bertahap dengan memperhatikan tahap perkembangan anak. pengenalan literasi dimulai dari mengenalkan bentuk huruf, membaca dan menulis kata hingga membaca dan menulis kalimat sederhana.

Media Pengenalan Literasi pada Anak Usia Dini di Kota Mataram

Media yang digunakan dalam pengenalan literasi pada anak usia dini sangat bervariasi, seperti kantong huruf, kartu huruf, puzzle huruf, buku cerita, pohon literasi, balok huruf, dimana dalam penggunaan media juga tergambar tahapan pengenalan literasi yang disesuaikan dengan usia dan kemampuan anak usia dini.

Metode Pengenalan Literasi pada Anak Usia Dini di Kota Mataram

Metode pengenalan literasi dengan metode bercerita, bermain, dan menyanyi. Capaian Kemampuan Literasi pada Anak Usia Dini di Kota Mataram

Kemampuan anak dalam membaca dan menulis permulaan dapat dilihat 
ketika sudah memasuki semester dua, khususnya kelas B. Rata-rata anak sudah mampu membaca kalimat sederhana.

\section{Implikasi Teoritis}

Secara teoritis, implikasi dari penelitian ini adalah:

1. Pengenalan literasi pada anak usia dini merupakan suatu hal yang sangat urgen untuk mendukung kesiapan anak untuk melanjutkan pendidikan ke jenjang berikutnya.

2. Pengenalan literasi pada anak usia dini harus memperhatikan metode, media dan tahapan pelaksanaannya dengan mengacu pada prinsip pembelajaran anak usia dini, yaitu belajar seraya bermain, beroriantasi pada kebutuhan anak, stimulasi terpadu, berorientasi pada perkembangan anak, lingkungan kondusif, dengan pendekatan tematik, bersifat aktif, kreatif, efektif dan menyenangkan, serta menggunakan berbagai media dan sumber belajar.

\section{Rekomendasi}

1. Bagi Guru Pendidikan Anak Usia Dini

Dari data hasil penelitian serta analisisnya yang mendeskripsikan pola pengenalan literasi pada anak usia dini di Kota Mataram. Guru PAUD di Kota Mataram direkomendasikan untuk memperkaya pengalaman literasi anak melalui metode dan media belajar yang variatif dengan memanfaatkan berbagai sumber.

2. Bagi penelitian selanjutnya Disarankan bagi penelitian selanjutnya untuk mmemetakan pola pengenalan literasi anak usia dini dengan cakupan subyek penelitian yang lebih besar dan mengkaji pencapaian kemampuan literasi anak secara kuantitatif.

\section{DAFTAR PUSTAKA}

Agus Suprijono, Cooperative Learning, Teori dan Aplikasi PAIKEM
(Yogyakarta: Pustaka Pelajar), 2011

Bisri Mustofa, Metode Menulis Skripsi dan Tesis, (Yogyakarta: Optimus, 2008)

Chandrawati, Strategi Pengembangan Kemampuan Membaca dan Menulis di TK Kelompok B, Jurnal pendidikan Anak Usia Dini Volume I no. 32003 (Jakarta: PPs UNJ, 2003)

Department for Education and Child Development. (2013). Numery+Literacy: a Numery and Literacy Strategy from Birth to 18. South Australia: Department for Education and Child Development

Doman\&Doman, How to Teach Your Baby to Read (Bagaimana Mengajar Bayi Membaca), (Jakarta: PT Tigaraksa Satria, 2006)

Hayat, Bahrul \& Suhendra Yusuf, 2010.Benchmark Internasional Mutu Pendidikan. Jakarta: Bumi Aksara

Hennatul Putri, Pengaruh permainan Konstruktif dan Kecerdasan Linguistic tarhadap Kemampuan Membaca Permulaan Anak Usia 5-6 Tahun, (Jakarta: Universitas Negeri Jakarta, 2008)

http://diniirawati.blogspot.co.id/2007/12/ pembelajaran-literasi-amak-usiadini.html?m=1

http://m.republika.co.id/berita/nasioal/um um/17/07/04/osk0p6-siswamasuk-sd-tak-boleh-lalui-tescalistung (diakses April 2017) 
Karisma, Team (Publishing Group). 2006.

Webster's

English

Dictionary.Jakarta: Karisma

Martini Jamaris, Pengembangan dan

Perkembangan Anak, Grasindo

Mustafa, Bulletin PADU Vol.5 No. 2,(

Agustus 2006

Sugiono, Metode Penelitian Pendidikan,

Bandung: Alfabeta, 2011

Syakir Abdul Azhim. (2011).

Membimbing Anak Terampil

Berbahasa. Depok: Gema Insani

Press

Syamsu Yusuf. (2004). Psikologi Perkembangan Anak \& Remaja.

Bandung: PT Remaja. 